\title{
Ormancılıkta ara teknik eleman sorununa yönelik çözümlemeler
}

\author{
Hasan Alkan,", Güler Erol Uğur
}

\begin{abstract}
Özet: Ormancılıkta ara teknik eleman sorununun ele alındığı bu çalışmanın başlıca amaçları (1) Orman muhafaza memurlarının eğitimi, eğitimle ilgili yaşanan sorunlar ve çözüm önerilerinin belirlenmesi, (2) Ormancıllk örgütlerinde görev yapmakta olan orman muhafaza memurlarının sorunlarının tespiti ve bunların çözümüne ilişkin önerilerin geliştirilmesi, (3) Orman işletme şeflerinin orman muhafaza memurlarına bakış açısının belirlenmesi ve (4) Ormancılık örgütlerinin ara teknik eleman bakımından yaşadığı sorunlar ve bunlara yönelik çözüm yollarının ortaya konulmasıdır. Araştırma kapsamında ormancılık ve orman ürünleri eğitimi alan önlisans ögrencileri (808 adet), fiilen çalışmakta olan orman muhafaza memurları (146 adet) ve orman mühendislerine (289 adet) yönelik anket çalışmaları yürütülmüștür. Araştırma sonucunda elde edilen bulgulara göre, orman muhafaza memurlarının eğitimi, istihdamı ve çalışma koşulları bakımından önemli sorunlar bulunmaktadır.

Anahtar kelimeler: Ormancılık, Ara teknik eleman, Orman muhafaza memuru, Eğitim, İstihdam, İş koşulları
\end{abstract}

\section{Analysis related to the technical assistant staff problem in forestry}

\begin{abstract}
The subject of this study is the technical assistant staff problem in forestry. The main aims of the study are; (1) The education of forest protection officers, the problems about the education and the solution suggestions of these problems, (2) The determination of forest protection officers' problems who work at the forestry organizations and to enhance the solution sugge stions of these problems, (3) The determination of the forest operation chiefs' viewpoint towards forest protection officers, (4) The problems of forestry organizations in terms of forest protection officers and to execute the solutions. The survey study had been conducted with students (808 questionnaires), technical assistant staff (146 questionnaires), and forest engineers (289 questionnaires). According to the findings of the study, there have been substantial problems in terms of forest protection officers' education, employment and working conditions.

Keywords: Forestry, Technical assistant staff, Forest protection officer, Education, Employment, Working conditions
\end{abstract}

\section{Giriş}

Orman varlı̆̆ının korunması ve toplumun orman ürün ve hizmetlerine olan ihtiyacının sürdürülebilir biçimde karşılanması anayasa ve yasalarla ormancılık örgütüne yüklenmiş bir görevdir. Bu görevin mümkün olduğunca eksiksiz bir şekilde yerine getirilebilmesi doğaya açık ve dağınık bir örgütlenmeyi zorunlu hale gerektirmektedir (Toksoy vd., 2012). Ormanlarımızın yönetimi ve işletilmesi başta Orman Genel Müdürlügü (OGM) olmak üzere Orman ve Su İşleri Bakanlığı'na bağ lı çeşitli genel müdürlükler ve taşra kuruluşları olan orman işletmeleri vasıtasıla gerçekleştirilmektedir (Daşdemir, 2011). Devlet orman işletmelerinin sürdürülebilirlik ilkeleri çerçevesinde görevlerini yapabilmeleri için tedarik, satın alma, araştırmageliştirme, yönetim, halkla ilişkiler, pazarlama, finansman, vb. gibi birçok işletme fonksiyonuna önem verme zorunlulukları bulunmaktadır (Daşdemir, 2003; Demir, 2015). Bu fonksiyonları eksiksiz bir şekilde icra edebilmek adına devasa bir örgüt haline gelen orman teşkilatı içerisinde farklı görev ve sorumluluk alanlarına sahip personel görev yapmaktadır. Ön lisans, lisans, yüksek lisans veya doktoraya sahip personel bulunabildiği gibi, görev yerlerine göre ilköğretim mezunları da çalışabilmektedir.
Orman mühendisleri, orman endüstri mühendisleri, inşaat mühendisleri, makine mühendisleri gibi birçok mühendis lik disiplininden personel bulunmakla birlikte muhasebeci, avukat gibi mühendis haricinde de personel istihdam edilebilmektedir. Ormancılık uygulamalarının yürütülmesi için ortaya konulan örgütlenme biçimi, ormancıllk personelinin temin-istihdamını ve eğitim-öğretimini çeșitlendirmiştir. $\mathrm{Bu}$ çeșitlilik, lisans düzeyindeki ormancılık eğitimi yanında, önlisans düzeyinde personel eğitimini de gerektirmektedir. $\mathrm{Bu}$ nedenle önlisans düzeyinde ormanc1lı eğitimi veren yükseköğretim programları açılmış durumdadır. Bu programlardan mezun olanlar, Orman ve $\mathrm{Su}$ İşleri Bakanlığ 1 ve bağlı kuruluş larında ara teknik eleman olarak ya da ormancıllkla ilgili mühendislik hizmetleri veren özel şirketlerde çalışabilmektedir (Koç vd., 2007). Ormancılıkta "ara teknik eleman" veya bir başka söylemle "teknik yardımc personel" denildiğinde ilk olarak orman muhafaza memurları, orman ağaçlandırma me murları, ölç me, kesim ve depo memurları gibi kadrolarda görev yapan personel akla gelmektedir (Tolunay, 2001; Genç ve Avc1, 2005). Son yıllardaki istihdamın orman muhafaza memurluğu şeklinde yapılmas1 ve ifade kolaylığ 1 sağlamak için anılan kadroların

\footnotetext{
\ a Süleyman Demirel Üniversitesi, Orman Fakültesi, Isparta

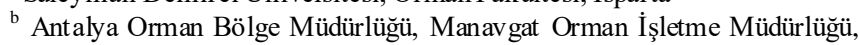
Antalya

@ * Corresponding author (İletişim yazarı): hasanalkan@ sdu.edu.tr

$\checkmark$ Received (Geliş tarihi): 25.11.2015, Accepted (Kabul tarihi): 24.05.2016
}

Citation (Atıf): Alkan, H., Erol Uğur, G., 2016. Ormancilıkta ara teknik eleman sorununa yönelik çözümlemeler. Turkish Journal of Forestry, 17(2): 132-141. DOI: $\underline{10.18182 / \mathrm{tif} .51481}$ 
tamamı yerine metnin bundan sonraki kısmında orman muhafaza memuru kavramı kullanılmıştır.

$\mathrm{Bu}$ araştırmada son yıllarda ormancıllk kamuoyunu meşgul eden konulardan biri olan orman muhafaza memurlarının eğitimi, iş ortamında yaşadıkları sorunlar ve orman işletmeleri bakımından verimlilikleri irdelenmiştir.

\section{Materyal ve yöntem}

Araştırma kapsamında üç farklı gruba yönelik anket çalışması yürütülmüştür. Bunlar,

- Meslek yüksek okullarının (MYO) ilgili bölümlerinde eğitim alan öğrenciler,

- Ormancilık örgütlerindeki amir posizyonunda olan orman mühendisleri ve

- Orman muhafaza memurlarıdır.

Anket çalışmalarında kullanılan model betimsel araştırma modelidir. $\mathrm{Bu}$ modelde amaç var olan durumu ortaya koymaktır. Dolayısıyla çalışmalarda kullanılacak olan formlarda deneklerin genel profil özellikleri, sosyal durumları, mesleğe bakış açıları ve meslekte karşıllaştığ1 sorunlar vb. hususlara yer verilmiştir. Soru tipi olarak çoktan seçmeli ve derecelemeli sorular kullanılmıştır. Orman muhafaza memurlarına yönelik anketler yüz yüze görüşme yöntemi ile yapıldığından araştırma evreni Antalya Orman Bölge Müdürlüğ̈ ile sınırlı tutulmuştur. Formlar hazırlandiktan sonra 2014 yılının mart-nisan aylarında 13 işletme müdürlüğünde görev yapmakta olan muhafaza memurlarıyla doldurulmuştur. Çalışmada bölge müdürlügünde görev yapmakta olan 193 muhafaza memurundan 146'sı ile anket çalışması yapılmıștır (Çizelge 1). Görüldüğü gibi bölge müdürlüğünde görev yapmakta olan muhafaza memurlarının \%75.6'lık kısmı çalışmaya katılmıştır.

OGM birimlerinde çalışan orman mühendislerine yönelik anket çalışmaları internet üzerinden ve online anket yöntemi ile yapıldığından anket formunda smırlı sayıda soruya yer verilmiştir. Anket intemet ortamında paylaşıldıktan sonra mail yoluyla orman mühendislerine duyurulmuş tur. Ankete 289 orman mühendisi katılmış tır.

Öğrencilere yönelik anket çalışmaları da internet üzerinden yürütülmüştür. Formalar internet ortamına aktarıldıktan sonra MYO yöneticileriyle görüşülerek formların yer aldığ 1 link onlarla paylaşılmış ve öğrencilerin anket çalışmasına katılımımı için gerekli duyuruların yapılması istenmiştir. Araştırmanın evrenini oluşturan programlardan anket çalışmasma toplam 808 öğrenci katılmıştır. Ancak bunlardan 17'si soruların büyük çoğunluğunu cevaplamamış; bu yüzden de değerlendirme kapsamı dışında bırakılmıştır (Çizelge 2).

Anketlerde yer alan sorular ve cevaplarının Ms excel programına aktarılması sırasında veriler sıra istatistiğine göre sayısallaştırılmıştır. Değerlendirmede ise Statistical Package for Social Science (SPSS) 15.00 paket programı kullanılmıştır. Analizlerde frekanslar, yüzdeler ve kikare $\left(\chi^{2}\right)$ bağıms ızlık testinden yararlanılmıştır (Özdamar, 2004; Eymen, 2007).

\section{Bulgular ve tartışma}

\subsection{Orman muhafaza memurlarınailişkin bulgular}

Antalya Orman Bölge Müdürlüğ̈̈'ndeki orman muhafaza memurlarının büyük çoğunluğu cinsiyet olarak erkek, medeni hal olarak ise evlidir. Profil özellikleri Çizelge 3'te verilmiştir.

Çizelge 1. Antalya Orman Bölge Müdürlüğü'ndeki orman muhafaza memurları

\begin{tabular}{lcc}
\hline Işletme Müdürlüğü & Standart Kadro & Mevcut Kadro \\
\hline Akseki & 30 & 15 \\
Alanya & 30 & 24 \\
Antalya & 36 & 35 \\
Elmalı & 11 & 6 \\
Finike & 22 & 12 \\
Gazipaşa & 22 & 13 \\
Gündoğmuş & 11 & 5 \\
Kaş & 24 & 16 \\
Korkuteli & 20 & 14 \\
Kumluca & 22 & 11 \\
Manavgat & 18 & 13 \\
Serik & 24 & 14 \\
Taşağll & 29 & 15 \\
\hline Toplam & 299 & 193 \\
\hline
\end{tabular}

Çizelge 2. Ankete katılan MYO'lar ve katılım oranları

\begin{tabular}{lc}
\hline MYO & Katılımcı Sayıs1 \\
\hline Yenişarbademli MYO & 385 \\
Sütçüler Prof. Dr. Hasan Gürbüz MYO & 117 \\
Kastamonu Ü. Araç MYO & 111 \\
Köyceğiz MYO & 66 \\
Atabey MYO & 33 \\
Bartın MYO & 31 \\
Gülnar MYO & 30 \\
Koyulhisar MYO & 15 \\
Mersin MYO & 9 \\
Çaycuma MYO & 6 \\
İstanbul Ü. Ormancıllk MYO & 2 \\
Almus MYO & 1 \\
Büyükorhan MYO & 1 \\
Kürtün MYO & 1 \\
\hline Toplam & 808 \\
\hline
\end{tabular}

Çizelge 3. Orman muhafaza memurlarının bazı profil özellikleri

\begin{tabular}{llr}
\hline Profil özellikleri & Seçenekler & $(\%)$ \\
\hline \multirow{4}{*}{ Yaş } & 24 ve altı & 7,5 \\
& $25-34$ & 18,5 \\
& $35-44$ & 5,5 \\
& $45-54$ & 51,4 \\
& $55+$ & 17,1 \\
\hline \multirow{2}{*}{ Eğitim durumu } & Lise & 65,8 \\
& Önlisans & 29,5 \\
& Lisans & 4,7 \\
\hline \multirow{2}{*}{ Medeni durum } & Evli & 81,5 \\
\multirow{2}{*}{ Çocuk sahipliği } & Bekar & 17,8 \\
\hline \multirow{2}{*}{ Cinsiyet } & Evet & 76,0 \\
& Hayır & 24,0 \\
\hline \multirow{4}{*}{ Meslekte geçen süre } & Kadın & 4,1 \\
& Erkek & 95,9 \\
\hline & 1 yıldan az & 12,3 \\
& $1-10$ yıl & 26,0 \\
& $11-20$ yıll & 9,6 \\
& $21-30$ y1l & 33,6 \\
& 30 yıldan fazla & 18,5 \\
\hline
\end{tabular}


Deneklerin \%56,8'i tamamen, \%33,6's1 da kımen olmak üze görevlerini tam olarak yerine getirdiklerini, geri kalanlar ise getiremediklerini söylemektedir. Görevlerini yerine getirmede engel olarak görülen hususlar ise Çizelge 4'teki gibidir. İş lerin kolaylaştırılması ve görevlerin eksiksiz yapılabilmesi için gerekli görülen hususlar ise Çizelge 5'te verilmiştir.

Görüldüğ̈̈ gibi, sonumluluk alanı genişliği, personel eksikliği ve özlük hakları önemli sorunlardır. Dolayısıyla bu hususların sorgulanmas1 gerekir. Deneklerin sorumluluk alanlarının ideal-olması gereken büyüklügüne yönelik görüş leri Çizelge 6'daki gibidir.

Sorumluluk alanının geniş olması sadece sorumlu olunan alanların büyüklüğü ile ilgili değil, aynı zamanda yapılan işin çeşidi ve yoğunluğuile de ilgilidir. Muhafaza memurlarının yapmakta olduğu işler ayrılan zamana göre Çizelge 7'de sıralanmıştır.

Deneklerin atama, yer değiştirme, yükselme uygulamaları hakkındaki görüşleri Çizelge 8'deki gibidir. Görüldüğü gibi sadece \% 7,5'lik kısım atama, yükseltme ve yer değiştirmelerde adil davranıldığ 1 görüşündedir.

Ücret konusu orman muhafaza memurlarinca her firsatta dillendirilen hususlardan birisidir. Deneklerin alınan ücretlere ilişkin memnuniyet durumlan Çizelge 9'daki gibidir. Buna göre deneklerin \%43,9'u aldığ 1 ücretten memnun değildir. 2015 yılı Temmuz ayında yapılan düzenlemelerle muhafaza memurları ortalama 2600-2700 TL maaş almaktadır. Ek gelirlerle birlikte 2015 yılı yangın döneminde bu rakam 3300 TL'ye ulaşmıștır.

Muhafaza memurlarının sosyal yaşama yönelik sorunlarınının belirlenebilmesi için "Çalışma alanınızda yaşadığınız sosyal sikıntıların öncelik strası nedir”,sorusu kullanılmıştır (Çizelge 10). Buna göre en öne çıkan şikayetlenme lojman-lokallerin yeters izliğidir.

Görevin sağlıklı bir şekilde icrası ve mesleki tatmin açısından kurum çalışanları ve üst yönetimce verilen destekler önemlidir. Deneklerin çok az kısmı herhangi bir sorun yaşanması halinde üst yönetimin desteğini tamamen gördüğünü söylemişlerdir (Çizelge 11). Meslektaş desteği ise, yönetici desteğine göre daha fazladır (Çizelge 12).

Çizelge 13'de deneklerin ormancıllk örgütünden olan beklentilerinin karşılanma dereceleri verilmiştir.

Çizelge 4. Görevlerin icrasını engelleyen hususlar

\begin{tabular}{lr}
\hline Engeller & $\%$ \\
\hline Sorumluluk alanının geniş olması & 16,4 \\
Değerlendirme ve ödüllendirme sist eminin olmayışı & 11,0 \\
Ücretlerin yetersiz oluşu & 10,3 \\
İletişim ve koordinasyon eksikliği & 9,6 \\
Personel Eksikliği & 8,2 \\
Politik engellemeler & 5,5 \\
Çalışma ortamı koşullarının yetersiz olması & 4,8 \\
Kişiliğinin görevin gerektirdiği yapıya uymaması & 4,1 \\
İş yükünün fazla olması & 3,4 \\
Çalışma arkadaşları ile iş uyumu sorunu & 3,4 \\
Alınan eğitimin yetersiz olması & 2,7 \\
Diğer & 20,6 \\
\hline
\end{tabular}

Çizelge 5. Yapılması gerekenlere ilişkin görüşler

\begin{tabular}{lr}
\hline Yapılması gerekenler & $\%$ \\
\hline Muhafaza memurlarının sorumluluk alanları daraltılmalıdır & 37,7 \\
İşletmelerdeki personel eksikleri giderilmelidir. & 30,1 \\
Özlük hakları iyileştirilmelidir & 26,0 \\
Politik baskılar kaldırılmalıdır & 6,2 \\
\hline
\end{tabular}

Çizelge 6. Çalışma alanı büyüklüğüneilişkin görüşler

\begin{tabular}{lc}
\hline Görüşler & $\%$ \\
\hline 5000 hektardan küçük & 14,4 \\
5000-15000 hektar & 35,6 \\
15000-25000 hektar & 32,2 \\
25000 hektardan büyük & 17,8 \\
\hline
\end{tabular}

Çizelge 7. İş çeşitlerinin önemi ve ayrılan zamanlara ilişkin görüssler

\begin{tabular}{lr} 
"En fazla zam anınızı alan iş önem sırasına göre hangisidir?" & $\%$ \\
\hline Üretim ve nakliye kesme işleri & 58,2 \\
Koruma faaliyetleri & 24,0 \\
Yangın söndürme & 11,6 \\
Silvikültürel işler & 2,1 \\
Kadastro işleri & 1,4 \\
Büro işleri & 2,7 \\
\hline
\end{tabular}

Çizelge 8. Örgütteki atama, yer değiştirme-yükseltme uygulamalarına ilişkin görüş ler

\begin{tabular}{lr}
\hline Görüşler & $\%$ \\
\hline Tamamen adil, başarı/tecrübeye göre yapılıyor & 7,5 \\
Adaletli davranılmıyor & 37,0 \\
Politik güçler etkili & 47,9 \\
Arkadaşlık ve çıkar ilişkileri dikkate alınıyor & 4,8 \\
Diğer & 2,8 \\
\hline
\end{tabular}

Çizelge 9. Ücret memnuniyetine ilişkin görüş ler

\begin{tabular}{lc}
\hline Memnuniyet durumu & $\%$ \\
\hline Memnun & 17,1 \\
Kismen memnun & 39,0 \\
Memnun değil & 43,9 \\
\hline
\end{tabular}

Çizelge 10. Sosyal sorunlara ilişkin görüşler

\begin{tabular}{|c|c|}
\hline Görüşler & $\%$ \\
\hline Lojman ve lokal gibi olanakların yetersiz oluşu & 43,2 \\
\hline $\begin{array}{l}\text { Mahrumiyet bölgesinde kültür-eğitim etkinliklerinin } \\
\text { k1sitlı olması }\end{array}$ & 23,3 \\
\hline Sağlık problemlerinde hekime ulaşma güçlügü & 2,7 \\
\hline $\begin{array}{l}\text { Çalıştığım bölgenin sosyal yapısının yaşam tarzım } \\
\text { uymaması }\end{array}$ & 2,1 \\
\hline Diğer (üstlerle olan sorunlar, ulaşım problemleri, vb.) & 28,7 \\
\hline
\end{tabular}

Çizelge 11. İhtiyaç halinde üst makamca verilen desteğe ilișkin görüşler

\begin{tabular}{lr}
\hline Görüşler & $\%$ \\
\hline Usst makamın kurumsal bir dest eğini görmedim & 39,7 \\
Üst makamın kurumsal desteğini nadiren gördüm & 24,7 \\
Üst makamın kurumsal desteğini orta düzeyde gördüm & 18,5 \\
Üst makamın kurumsal desteğini çoğu zaman gördüm & 13,0 \\
Üst makamın kurumsal desteğini daima gördüm & 4,1 \\
\hline
\end{tabular}

Çizelge 12. Mes lektaşlarca verilen desteğe iliş kin görüş ler

\begin{tabular}{lc}
\hline Görüşler & $\%$ \\
\hline Üst makamın kurumsal bir dest eğini görmedim & 28,8 \\
Desteklerini nadiren gördüm & 29,5 \\
Desteklerini orta düzeyde gördüm & 15,8 \\
Desteklerini çoğu zaman gördüm & 15,8 \\
Desteklerini daima gördüm & 10,1 \\
\hline
\end{tabular}

Çizelge 13. Ormancılık örgütünden beklentilerin karşılanma durumu

\begin{tabular}{lr}
\hline $\begin{array}{l}\text { "Ormancılık örgütüne katılıkeki } \\
\text { gerçekleşti?" }\end{array}$ & beklentileriniz ne ölçüde \\
\hline Hiç gerçekleşmedi & 13,7 \\
Çok az gerçekleşti & 35,6 \\
Orta düzeyde gerçekleşti & 39,0 \\
Büyük ölçüde gerçekleşti & 8,9 \\
Tamamen gerçekleşti & 2,8 \\
\hline
\end{tabular}


Deneklerin mesleki konulardaki çeşitli yargılara ilişkin düşünce ve tutumları ise Çizelge 14 'de verilmiş ve ardından gerekli görülen önerme-yargılar irdelenmiştir.

Çizelge 14'de görüldüğü gibi katılımcıların \%89,7 MYO'larda orman muhafaza memurları yetiştirmeye yönelik açılan ormancıllkla ilgili bölüm ve programların gerekli olduğunu düşünmektedir. Bununla birlikte memurların lise, önlisans veya lisans mezunu olup olmamaları ile MYO'lardaki program ve bölümleri gerekli görüp, görmeme arasında istatistiksel olarak anlamlı bir iliş ki söz konusu değildir $\left(X^{2}=6,837, \mathrm{sd}=8, \mathrm{P}>0,05\right)$. Benzer şekilde diğer profil özellikleri ile de bu anlamda istatistiksel olarak anlamlı bir ilişki tespit edilememiştir. Ormancılık örgütünde hizmet içi eğitimler değiş en mevzuat ve teknikler doğrultusunda zaman zaman düzenlenmekte olup, personelin \%88,4'ü bu eğitimlerin yararlı olduğu önermesini desteklemektedir. Bununla birlikte deneklerin yaklaş $1 \mathrm{k}$ \%40,0'1 hizmet içi eğitimler sayı ve içerik olarak yetersiz bulmaktadır. Hizmet içi eğitimler daha ziyade izin irtifak, üretim ve yangın alanlarında verilmektedir. Kadastro, teknik aletlerin kullanımı ve iletişim konularında da eğitim talebi sözkonusudur.

Orman muhafaza memurları hali hazırda Tarım-Orman Çalışanları Birliği Sendikası (TOÇBİRSEN), tarım ve Ormancılık Hizmet Kolu Kamu Emekçileri Sendikası (TARIM ORKAMSEN), Türkiye Tarım Orman ve Gida Hizmet Kolu Kamu Görevlileri Sendikası (TÜRK TARIM ORMAN-SEN), vb. gibi sendikalara üye olabilmektedir. Sendikalaşmanın hızla devam ettiği bu dönemde deneklerin $\% 59,6$ 's1 sendikaların mesleğin menfaatleri doğnultusunda hareket etmediğini ve yararlı işlerle uğraşmadı̆̆ını düşünmektedir.

"Ormancllk mesleği toplum nezdinde yeterince itibar görmektedir." şeklinde verilen önermeye deneklerin sadece \%39'u katılmaktadır. "Çocuklarımdan birinin ya da akrabalarımın bu meslekte olmasını isterim." şeklinde verilen önermeye deneklerin sadece \%32,9'u olumlu cevap verirmiştir. Deneklerin \%52'si firsatı olması durumunda orman muhafaza memurluğu yerine başka bir iş yapmak istediğini ifade etmektedir. Ülkemizdeki işsizlik oranının hergeçen gün arttı̆g 1 ve insanların devlet kapsısinda işi bulma meraklarına rağmen, mesleğe yönelik memnuniyetsizlik oranın yüksek olması dikkat çekicidir. Diğer yandan, kikare analizi bulgularına göre ormancıllk mesleğinin toplum nezdinde itibarının yeterli olmadığını düşünmekle, yakınlarından birisinin orman muhafaza memuru olmasin1 isteyip istememe aras inda istatistiksel olarak anlamlı bir ilişki söz konudur $\left(X^{2}=42,413\right.$, sd=16, $\mathrm{P}<0,05)$. Meslek itibarı ile baş ka işte çalışma isteği aras ında da istatistiksel olarak anlamlı bir iliş ki bulunmaktadır $\left(X^{2}=\right.$ $32,700, \mathrm{sd}=16, \mathrm{P}<0,05)$.

Deneklerin \%63,0'ı çalışmakta olduğu birimin uzmanlık alanına uygun olduğunu ifade etmektedir. Uzmanlık alanlarıyla uyumlu birimlerde çalışmak iş verimliliği ve motivasyonu arttırıcı uns urlar olarak kabul edilebilir.

Kolluk kuvveti olması nedeniyle 24 saate tabi olarak çalışan orman muhafaza memurlarının \%52,7'si çalışma saatlerinden memnun değildir. Deneklerin sadece \%47,9'ü yıllı iznlerini istedikleri zamanda kullanabilmiş durumdadır. Deneklerin \%66,4'ü iş koşulları nedeniyle ailesine yeterli zaman ayıramamaktan şikâyetçidir. Deneklerin \%47,9'u da mobinge maruz kaldıklarını ifade etmektedir.

Antalya Orman Bölge Müdürlüğ̈̈’nde norm kadroların yaklașık \%33,3'lük kısmı boștur (Bkz. Çizelge 1). Dağılımlardaki problemler de dikkate alındığmda bazı işletme müdürlükleri ya da şefliklerde ara teknik eleman sorunun yaşanacağ 1 aşikârdır. Deneklerin \%52,7'si şefliklerdeki personel sayısının yetersiz olduğunu ifade ederken, \%82,2'si de teşkilatın daha fazla personel alması gerektiğini söylemektedir. Bununla birlikte deneklerin \%76,0'1 mevcut pers onel alım yöntemini onaylamamaktadır. Mevcut sınav sisteminin mesleki bilgi ve beceri ölçmeye yönelik olmadığ1 ve mülakat-sözlü sınav uygulamalarında adaletin sağlanmasının zorluğu dikkate alındığında bu değerlendirmenin son derece yerinde olduğu söylenebilir.

Çizelge 14. Mes lekikonulardaki çeşitli yargılara iliş kin düşünceler

\begin{tabular}{|c|c|c|c|c|c|}
\hline Yargilar-önermeler & $\begin{array}{c}5 \\
(\%)\end{array}$ & $\begin{array}{c}4 \\
(\%)\end{array}$ & $\begin{array}{c}3 \\
(\%)\end{array}$ & $\begin{array}{c}2 \\
(\%)\end{array}$ & $\begin{array}{c}1 \\
(\%)\end{array}$ \\
\hline MYO'larda muhafaza memuru yetiştirmeye yönelik açılan ormancılık programları gereklidir & 69,2 & 20,5 & 4,8 & 4,1 & 1,4 \\
\hline Hizmet içi eğitim mesleğimiz için yaralıdır & 60,3 & 28,1 & 4,8 & 2,7 & 4,1 \\
\hline Sendikaların meslek menfaatleri doğrultusunda hareket ettiğini düşünüyorum & 14,4 & 11,6 & 14,4 & 21,2 & 38,4 \\
\hline Ormancılık mesleği toplum nezdinde yeterince it ibar görmektedir & 17,8 & 21,2 & 24,7 & 23,3 & 13,0 \\
\hline Çocuklarımdan birinin ya da akrabalarımın bu meslekte olmasını isterim & 21,9 & 11,0 & 11,6 & 19,9 & 35,6 \\
\hline Fırsatım olsa ormancılık mesleği dışında bir meslekte çalışmak ist erim & 32,1 & 19,9 & 16,4 & 15,8 & 15,8 \\
\hline Çalışmakta olduğum birim uzmanlık alanımla uyumludur & 25,3 & 37,7 & 14,4 & 14,4 & 8,2 \\
\hline Çalışma koşullarımız nedeniyle ailemeyeterli zaman ayıramıyorum & 46,5 & 19,9 & 10,3 & 13,0 & 10,3 \\
\hline Çalışma saatleri bakımından memnunum & 17,1 & 19,2 & 11,0 & 18,5 & 34,2 \\
\hline Y1llı izinlerimiz yeterlidir veher istediğimde kullanabiliyorum & 22,6 & 25,3 & 13,0 & 15,8 & 23,3 \\
\hline Kurum içinde herhangi bir nedenle mobinge maruz kalma oranı yüksektir & 25,3 & 27,4 & 19,9 & 15,8 & 11,6 \\
\hline Kurumu içinde görev ve sorumluluklarımız açıkça tanımlanmış durumdadır & 25,3 & 30,8 & 12,3 & 15,8 & 15,8 \\
\hline Daha fazla personele ihtiyaç vardır & 56,9 & 25,3 & 4,1 & 7,5 & 6,2 \\
\hline Mevcut orman muhafaza memuru alım şeklini doğru bulmuyorum. & 49,3 & 26,7 & 7,5 & 6,2 & 10,3 \\
\hline Ormancılıkla ilgili kanunlarda güncelleştirme yapılmalı ve halk lehine adımlar at ılmalıdır & 36,4 & 30,1 & 16,4 & 7,5 & 9,6 \\
\hline Ormancılık mesleğinin örgüt yapısının mesleğin icrası bakımından yeterli görüyorum & 19,9 & 27,3 & 19,9 & 19,2 & 13,7 \\
\hline Görevimiz gereği orman köylüsü ile sık sık sorun yaşıyorum & 28,1 & 20,5 & 15,1 & 24,7 & 11,6 \\
\hline Dikli satış uygulamaları iş yükümüzü artırmıştır & 24,7 & 20,5 & 12,3 & 21,9 & 20,6 \\
\hline Ormancılık mevzuatı fazla katıdır.Toplumla aramızın açılmasına neden olmaktadır & 25,4 & 20,5 & 13,7 & 21,9 & 18,5 \\
\hline Şefliklerdeki muhafaza memuru sayısı yeterlidir & 21,3 & 13,0 & 13,0 & 21,9 & 30,8 \\
\hline Son yıllarda yapılan rehabilitasyon çalışmaları ormancılığımıziçin yararlı olmuştur & 25,3 & 29,5 & 24,0 & 8,2 & 13,0 \\
\hline Son yıllarda ot latma ile ilgili yapılan düzenlemeler yerindedir & 20,5 & 30,8 & 24,0 & 15,1 & 9,6 \\
\hline Mesleğimin geleceğini olumlu görüyorum & 17,2 & 16,4 & 26,7 & 11,6 & 28,1 \\
\hline
\end{tabular}

* 5:kesinlikle katıllyorum, 4:katılıyorum, 3:Karasızım, 2: katılmıyorum, 1: kesinlikle katılmıyorum 
Deneklerin \%48,6's1 görevi gereği orman köylüsü ile sık sık karșı karşıya geldiklerini hatta sorunlar yaşayabildiklerini söylemektedir. Deneklerin \%45,9'u bu sorunların asıl kaynağı olarak orman kanunu ve ilgili diğer mevzuatın katılığına bağlamaktadır.

Deneklerin sadece \%33,6's1 mesleğin geleceğine ilişkin olumlu bir görüşe sahiptir. Konuya ilişkin kararsızların oran1\%26,7 iken, olumsuzgörenler ise \%39,7'dir.

\subsection{Orman mühendislerinin orman muhafaza memurlarna ilişkingörüşleri}

Araştırma kapsamında orman muhafaza memurlarının çalıştı̆̆ 1 birimlerde amir pozisyonunda olan orman mühendis leri ile de anketler yapılmıştır. Araştırmaya katılan mühendislerin Yaklaşık \%90'1 erkek ve \%81'i de evlidir. Orman mühendislerinin diğer profil özellikleri ise Çizelge 15'deki gibidir.

Orman mühendislerinin muhafaza memurlarına ilișkin çeşitli konulardaki görüşleri ise Çizelge 16'daki gibidir. Görüldüğü gibi, deneklerin \%67,0'1 orman muhafaza memurlarının iş yükünün çok olduğunu yönünde verilen önermeyi desteklemektedir. Öte yandan, deneklerin \%53,0'1 muhafaza memurlarının unvan değişikliği ile işletme şefi olmasını doğru bulmamaktadır. Zira bu şekilde işletme şefi olan orman muhafaza memurları ile orman mühendisliği mezunu olan işletme şefi adayları aras inda haksız rekabetin ortaya çıktığını düşünmektedirler. Ayrıca bir taraftan görev yaparken, diğer taraftan lisans eğitimini tamamlamaya çalışan memurlarının çalıştığı birime olan katkısı da düşük olabilmektedir.

Deneklerin \%56's1 MYO'larda verilen eğitimin uygulamaya dönük bilgiler bakımından yetersizlikler olduğunu dolayssıyla da muhafaza memurluğu için yeterli olmadığını ifade etmektedir. Deneklerin \%70'i orman muhafaza memuru ile işletme şefi aras inda bir ara teknik eleman olması gerektiğinidüşünmektedirler.

Deneklerin \%65'i orman muhafaza memurlarının yaptıkları işe göre aldıkları maaşı az bulmaktadır. Mesai saati kavramina dikkat etmeden orman muhafaza memurları fedakârca çalışmaktadır. Bu çalışma koşulları kabul edilebilir bir durum olma makla birlikte çalıştıkları bu fazla saatler için herhangi bir ek ücret hakları bulunmamaktadır. Sosyal hayatın kisitlanması ise ayrı bir trajik durumdur. Alınan maaş ile gösterilen performans uyumlu olmalıdır. Antalya Orman Bölge Müdürlüğü düşünüldüğünde, Gündoğmuş Orman İsletme Şefliğinde çalışan orman muhafaza memuru ile diğ er orman işletme müdürlüklerinde çalışan orman muhafaza memuru aynı maaşıalmamalıdır.

Çizelge 15. Orman mühendislerinin profilözellikleri

\begin{tabular}{|c|c|c|}
\hline Profil Ozellikleri & & $\%$ \\
\hline \multirow{2}{*}{ Cinsiyet } & Erkek & 89,7 \\
\hline & Kadın & 10,3 \\
\hline \multirow{4}{*}{ Yaş gurupları } & $25-34$ & 42,6 \\
\hline & $35-44$ & 30,8 \\
\hline & $45-54$ & 21,8 \\
\hline & $55+$ & 4,8 \\
\hline \multirow{4}{*}{ Eğitim durumu } & Lisans & 79,5 \\
\hline & Yüksek Lisans & 16,4 \\
\hline & Doktora & 2,4 \\
\hline & İki fakülte mezunu & 1,7 \\
\hline \multirow{2}{*}{ Medeni durumu } & Evli & 80,6 \\
\hline & Bekar & 19,4 \\
\hline \multirow{5}{*}{ Çocuk sahipliği } & Yok & 31,8 \\
\hline & 1 çocuk & 21,1 \\
\hline & 2 çocuk & 36,7 \\
\hline & 3 çocuk & 10,4 \\
\hline & 4 ve fazlası & 0 \\
\hline \multirow{5}{*}{ Hizmet süresi } & 1 yildan az & 5,2 \\
\hline & $1-5 \mathrm{y} 11$ & 21,1 \\
\hline & $5-15$ yıl & 34,6 \\
\hline & $16-25$ y1l & 27 \\
\hline & 26 yıl ve üzeri & 12,1 \\
\hline \multirow{7}{*}{$\begin{array}{l}\text { Görev yaptıkları } \\
\text { birimler }\end{array}$} & Orman işletme şefliği & 43,6 \\
\hline & $\begin{array}{l}\text { Orman işl.müd. yard. orm. işl. müd. } \\
\text { veya şube müdürlüğü }\end{array}$ & 16,6 \\
\hline & $\begin{array}{l}\text { İşl. müd., bölge müd.veya bakanlık } \\
\text { bünyesinde mühendis }\end{array}$ & 19,4 \\
\hline & Kadastro komisyonu veya & 3,5 \\
\hline & $\begin{array}{l}\text { amenajman heyetinde mühendis } \\
\text { Bölge müdür yard., bölge }\end{array}$ & \\
\hline & müdürü,daire başkanlığı & 2,4 \\
\hline & Diğer & 14,5 \\
\hline
\end{tabular}

Çizelge 16. Orman mühendis lerinin orman muhafaza memurlarına ilişkin görüşleri

\begin{tabular}{|c|c|c|c|c|c|}
\hline Yarg1-önermeler & $\begin{array}{c}5 \\
(\%)\end{array}$ & $\begin{array}{c}4 \\
(\%)\end{array}$ & $\begin{array}{c}3 \\
(\%)\end{array}$ & $\begin{array}{c}2 \\
(\%)\end{array}$ & $\begin{array}{c}1 \\
(\%)\end{array}$ \\
\hline Orman muhafaza memurlarının iş yükünün çok olduğunu düşünüyorum & 28 & 39 & 14 & 13 & 6 \\
\hline Orman muhafaza memurlarının unvan değişikliği ile işletme şefi olmalarını doğru bulmuyorum. & 33 & 20 & 11 & 23 & 13 \\
\hline Meslek Yüksekokullarında verilen eğitimin orman muhafaza memurluğu için yeterlidir & 7 & 19 & 18 & 32 & 24 \\
\hline İşletme şefleri ile orman muhafaza memurlan arasında tekniker gibi ara teknik eleman olmalıdır & 44 & 26 & 7 & 14 & 9 \\
\hline Orman muhafaza memurlarının yaptıklanı ișe göre aldıklarımaaşı az buluyorum & 29 & 36 & 18 & 12 & 5 \\
\hline
\end{tabular}

* 5: kesinlikle katılıyorum, 4:katılıyorum, 3:Karasızım, 2: katılmıyorum, 1: kesinlikle katılmıyorum 


\subsection{Ormancılık ĕgitimigören öğrencilere yönelik bulgular}

Çalışmakta olan kesimde olduğu gibi öğrenim görmekte olan kesimde de erkeklerin sayıs 1 kadınlara nazaran oldukça fazladır. Zira deneklerin yaklaşık \%90'1 erkektir (Çizelge 17).

Deneklerin \%16,8'inin ailesi şehir merkezlerinde, \%42,7'sinin ailesi ilçe merkezlerinde, \%34,4'ünün ailesi köyde, \%4,9'unun ailesi ise kasabada ikamet etmekte ve yaşamlarını sürdürmektedir. Öğrencilerin \%26,5'inin baba mesleği çiftçiliktir. Öğrencilerin \%23'ünün babas1 emekli, $\% 10,7$ 'sininki memur ve \%10,6's mnnki esnaftır. \%1,3'lük kesimimin babası ise hayvancılıkla uğraşmaktadır. Baba mesleği ile ilgili soruya deneklerin \%27,4'ü diğer cevabını vermiş \%0,4'ü ise bu soruyu cevapsız bırakmıştır. Deneklerin \% 90'ının annesi ev hanımıdır. Çalışan anne $\% 7,6$ olup, deneklerin \% 2,4'ü bu sonuyu cevaps $1 z$ bırakmıştır. Baba-anne çalışma durumu ile ilgili bulgular Alkan (2013) ile benzerlik göstermektedir.

Deneklerin barınma yerleri, aylık gelirlerinin yeterliliği ve burs-çalış ma durumu bilgileri Çizelge 18 deki gibidir.

Öğrencilerin akademik başarı durumları çeşitli etmenlere bağlı olarak şekillenmektedir. Başarı ya da başarısıllı̆̆n en somut göstergesi ise öğrenci genel not ortalamalanıır. Üniversite mevzuatına göre genel not ortalaması 2,0'in altında olan öğrenciler başarısız sayılmaktadır. Deneklerin not durumu, mezun olduğu lise ve alanlar Çizelge 19'daki gibidir.

MYO'ların iyi bir programından mezun olur olmaz daha kısa sürede hayata atılma olanağının olması ve yükseköğretim mevzuatı ile meslek liselerinden MYO'lara sınavsız geçiş olanağının sağlanması gibi nedenlerle deneklerin önemli bir bölümünün $(\% 59,5)$ meslek lisesi kökenli olduğu görülmektedir. 4702 sayılı yasa ile orta öğrenimdeki ve teknik okullardan mezun olanlara istedikleri takdirde orta öğrenimdeki bitirdikleri programın devamı niteliğindeki ya da buna en yakın programların uygulandığ 1 MYO'lardaki programlara sınavsız kayıt hakkı verilmiştir (Keskin vd., 2010). Deneklerin \%43,6's1 sinavsız geçiş hakkından yararlanarak geri kalan \%54,7'si ise sınav sonuçlarına göre programa yerleşmiş olup \% 1,6's1 bu soruyu yanıtsız bırakmıştır. Son günlerde meslek liselilerimn MYO'lara sınavsız geçiş avantajının azaltılmasına yönelik çalışmaların olduğu söylenmektedir. Zira, Ülke genelinde önlisans kontenjanlarının \% 60,0'ının sınavsız geçiş ile, \% 40,0'1 YGS puanı ile yerleşmeye ayrıldığ 1 tahmin edilmektedir. $\mathrm{Bu}$ değişiklik ilk görüşte önemli değilmiş gibi gözükse de teknik anlamda önemli sonuçları beraberinde getirmektir. Çünkü eski uygulamada MYO kontenjanlarma öncelikle ilgili meslek lisesi mezunları sınavsız şekilde yerleşiyor, boş kontenjan kalırsa, bu kontenjanlara diğer lise alanlarında mezun adaylar YGS puanları ile yerleşebiliyorlardı(EA, 2015).

Öğrencilerin tercih yaparken mezun olduklarında kolay iş bulabilecekleri, iyi para kazanabilecekleri meslekleri dikkate almaları beklenen bir durumdur (Nartgün ve Yüksel, 2009, Alkan, 2013). Deneklerin \%13,0'1 kaçınc1 tercihle programa yerleştiklerini hatırlamamaktadır. Hatırlayanların büyük bir bölümü ise programa ilk 5 tercihi içinden yerleşmiştir. Sadece \%7,1'lik kısım programı tesadüfen seçmiş, diğerleri ise bilinçli olarak tercih etmişlerdir. Deneklerin önemli bir kısmı $(\% 90,0)$ program-bölüm hakkında tercih yapmadan daha önceden bilgi sahibidir. Bilgi kaynakları ise sırasıyla öğretmen ve okul/dershane arkadaşları $(\% 44,2)$, mesleği icra eden yakınlar $(\% 25,9)$ ve aile $(\% 11,9)$, basin $(\% 1,8)$ ve diğer $(\% 16,2)$ şeklinde siralanabilir.

Çizelge 17. Öğrencilerin bazı profil özellikleri

\begin{tabular}{llr}
\hline Profil özellikleri & Seçenekler & $\%$ \\
\hline \multirow{2}{*}{ Cinsiyet } & Erkek & 89,4 \\
& Kadın & 8,5 \\
& Cevapsız & 2,1 \\
\hline \multirow{3}{*}{ Eğitim aldı̆̆ } & Ormancilik ve Orman Ürünleri & 76,2 \\
program & Programı & \\
& Orman muhafaza memuru & 21,9 \\
& olabilecek diğer programlarda & \\
& Cevapsız & 1,9 \\
\hline \multirow{2}{*}{ Sinıf ve birinci- } & Birinci sinıf birinci öğretim & 35,5 \\
ikinci öğretim & İkinci sinıf birinci öğretim & 23,1 \\
durumu & Birinci sinıf ikinci öğretim & 25,3 \\
& İknci sinıf ikinci öğretim & 16,1 \\
\hline
\end{tabular}

Çizelge 18. Öğrencilerin barınma, aylık gelir, burs ve çalışma durumları

\begin{tabular}{|c|c|c|}
\hline $\begin{array}{l}\text { Profil } \\
\text { özellikleri }\end{array}$ & Seçenekler & $\%$ \\
\hline \multirow{5}{*}{ Barınma yeri } & Aile ile birlikte & 7,0 \\
\hline & Aileden ayrı bir evde & 33,6 \\
\hline & Devlet yurdunda & 8,0 \\
\hline & Özel yurtta & 39,4 \\
\hline & Diğer & 12,0 \\
\hline \multirow{5}{*}{$\begin{array}{l}\text { Aylık gelirin } \\
\text { yeterliliği }\end{array}$} & Evet kesinlikle & 23,8 \\
\hline & Kismen & 45,9 \\
\hline & Hayır & 27,1 \\
\hline & Kararsizim & 2,8 \\
\hline & Cevapsiz & 5,0 \\
\hline \multirow{4}{*}{$\begin{array}{l}\text { Çalışma } \\
\text { durumu }\end{array}$} & Evet, yazın ve ara tatilde & 47,7 \\
\hline & $\begin{array}{l}\text { Evet, okul döneminde kısmi zamanlı } \\
\text { olarak }\end{array}$ & 10,9 \\
\hline & Hayır çalıșmiyorum & 41,1 \\
\hline & Cevapsiz & 0,4 \\
\hline \multirow{4}{*}{ Burs durumu } & Evet, Kredi ve Yurtlar Kurumundan & 43,2 \\
\hline & $\begin{array}{l}\text { Evet, Kredi ve Yurtlar Kurumu } \\
\text { haricinde baska bir yerden }\end{array}$ & 3,3 \\
\hline & Hayır almiyorum & 52,3 \\
\hline & Cevapsiz & 1,1 \\
\hline
\end{tabular}

Çizelge 19. Oğrencilerin not ortalamaları, mezun olduğu lise ve alanlar

\begin{tabular}{llr}
\hline Değişkenler & Seçenekler & $\%$ \\
\hline \multirow{4}{*}{ Not ortalaması } & $2,0<$ & 17,3 \\
& $2,0-2,5$ & 25,4 \\
& $2,5-3,0$ & 30,6 \\
& $3,0-3,5$ & 20,9 \\
& $>3,5$ & 5,8 \\
\hline \multirow{4}{*}{ Mezun olunan lise türü } & Düz lise & 31,1 \\
& İmam hatip lisesi & 3,8 \\
& Anadolu Lisesi & 5,4 \\
& Cevapsiz & 1,0 \\
& Meslek lisesi & 59,5 \\
\hline \multirow{3}{*}{ Lisede mezun olduğunuz alan } & Say1sal & 23,5 \\
& Sözel & 16,9 \\
& Eşit ağırlık & 23,4 \\
& Mesleki eğitim & 36,2 \\
\hline
\end{tabular}


Deneklere sorulan "Bugün tekrar tercih yapma şansinız olsa ormancllı ve orman ürünleri programinı yine tercih eder miydiniz?" şeklinde sonulan bir sonuya \%81,0 evet, $\% 12,0$ ise hayır cevabı alınmıştır. Deneklerin $\% 7,01$ ise bu konuda kararsız olduklarını ifade etmiştir. Öğrencilerin programı tercih nedenlerini belirleyebilmek amaciyla " $B u$ programı neden seçtiniz?" şeklinde bir sonu sonulmuştur. Deneklerin \%84,8'i orman muhafaza memuru olabilmek için, \%9,2'si dikey geçişle orman fakültelerine geçebilmek için, \%0,8'i herhangi bir üniversite diplomasına sahip olabilmek için (ormancılık mesleğini yapıp yapmama önemli değil), \%0,5'i askerliği ertelemek için ve \%0,4'ü de mevcut memuriyet görevinde (zaten memur olarak çalışıyor) bir derece yükselebilmek için şeklinde soruyu yanıtlamıştır. Deneklerin \%0,9'u bu soruyu cevapsız bırakırken; \%3,4'ü ise hiçbiri yanıtını vermiştir. Deneklerin \%70,7'si okuduğu programı seçmeye lisedeyken karar vermiştir. Bu kararı üniversitenin baş ka bir biriminde eğitim alırken verenlerin oran 1 is e $\% 8,3$ 'tür.

Yukarıda belirtilen bazı değișkenlerin akademik bașarı yani not ortalamas ma olan etkilerinin istatistiksel olarak anlamlı olup olmadığının araştırılması amacıyla kikare testi yapılmıştır. Buna göre, not ortalaması ile mezun olunan lise tü̈̈̈ ( $\left.X^{2}=140,697, \mathrm{sd}=16, \mathrm{P}<0,05\right)$, me zun olunan dal-alan $\left(X^{2}=125,931, \mathrm{sd}=12, \mathrm{P}<0,05\right)$, cinsiyet $\left(X^{2}=59,463, \mathrm{sd}=8\right.$, $\mathrm{P}<0,05)$, s mavla $\mathrm{m}$ yoksa geçis hakkından yararlanarak mı programa yerleştiği $\left(X^{2}=195,699, \quad \mathrm{sd}=8, \quad \mathrm{P}<0,05\right)$ ve programı bilinçli olarak tercih edip etmediği $\left(X^{2}=48,164\right.$, $\mathrm{sd}=20, \mathrm{P}<0,05)$ arasında istatistiksel olarak anlamlı ilişki tespit edilmiştir.

Ormancilik kamuoyunda orman muhafaza memurlarının kimler arasından seçilmesi gerektiği ve eğitimi konusunda tartı̧̧malı ve halen belirginleşememiş hususlar bulunmaktadır. "Orman muhafaza memurlar mutlaka MYO'larca yetiştirilmelidir." şeklinde sunulan önermeye öğrencilerin \%85,0’1 katılım göstermiştir. Konuya ilişkin karasız olanların oranı ise \%10,0'dır. \%5,0'l1k k1sım ise önermeye katılmamaktadır. "Ormancılık-orman ürünleri programı haricindeki programlardan orman muhafaza memuru atanmasını doğru bulmuyorum." önermesine katılım ise \% $\%$ 'dir.

Deneklerin çeşitli konularda sunulan önermelere ilişkin düşünceleri ise Çizelge 20.'de özetlenmiştir. Buna göre, "Ormanlarımızın korunup geliştirilebilmesi için orman muhafaza memurlarnna mutlaka ihtiyaç vardır. Bu ihtiyaç günden güne artmaktadır" önermes ine deneklerin \%92,8' $\mathrm{i}$ katılım göstermiştir. Deneklerin yarıdan fazlası (\%58,4'tür) orman muhafaza memurluğunun toplum tarafindan yeterince bilindiğini söylemektedir. Mesleğin toplum nezninde itibarlı olduğunu söyleyenler ise \%61,3'tür. Ormancılık kamouyu bakımından tarışmalı konulardan birisi de yine daha önce ifade edildiği gibi orman muhafaza memurlarının orman mühendisi olabilmeleri ve bu konuda haksız rekabetin olduğuna yöneliktir. Öğrencilerin konuya ilişkin görüşlerini belirlemek için "Orman muhafaza memurlarının dikey geçiş yoluyla orman fakültelerinde lisans eğitimi alması meslek için yararlıdır." ve "Mezun olur olmaz dikey geçişle orman mühendisliği bölümüne geçmeyi planliyorum" önermeleri kullanılmıştır. Birinci önermeye katılım oranı oldukça yüks ektir $(\% 89,0)$. Bununla birlikte öğrencilerin yaklaşık yarıs1 $(\% 54,0)$ mezun olunca dikey geçişi zorlayacağını ifade etmektedir. MYO'ların ilgili programlarından mezun olan öğrencilerin orman muhafaza memuru olarak atanma şans1 bulmas1 ve atamaların düzenli sayılabilecek şekilde birkaç yıl ard arda devam etmesi neredeyse her üniversitede bir ormancillk programı ya da bölümünün açılmasına yol açmış ve yıllık kontenjan sayısı da yıldan yıla artmıştır. Hal böyle olunca mezunların istihdamı bakımndan çok ciddi sorunlar yaşanmaya başlanmıştır. "Muhafaza memuru yetiştirmeye yönelik açılan mevcut programlar yeterlidir. Yeni programların açılmasına karşııı." şeklinde verilen önermeye öğrencilerin \%58,0'1 katılmaktadır. Öğrencilerin $\% 20,0$ '1 hala yeni programların açılması gerektiğine inanmaktadır. Konuya ilişkin kararsızların oranı ise $\% 22,0$ 'dir.

MYO ve buralarda ormancılıkla ilgili bölümprogramların hızla artması sonucu gündeme gelen husus lardan birisi de okullardaki fiziki olanaklar ve verilen eğitimin yeterliliği üzerinedir. $\mathrm{Bu}$ bağlamda öğrencilerin, okulda aldıkları eğitimin yeterliliği, verilen derslerin sayı ve içerik olarak yeterliliği, okuldaki fiziksel koşulların ve staja yönelik sağlanan olanakların yeterliliği gibi pek çok husus bakımından önemli endişeler bulunmaktadır. "Okulumuzun fiziksel olanaklan (Laboratuar, çalışma salonları, kantin, spor salonlarl, vb. bakımdan) yeterlidir" önermesine katılım oranı sadece $\% 24,0$ 'dır. Öğrencilerin $\% 13,0$ '1 bu konuda kararsız olduklarını ifade etmişlerdir. Okulların fiziksel olanaklarının kötü olmasının etkisi bu okulların genellikle ilçelerde kurulmalarıyla daha fazla hissedilmektedir. "Okulumun bulunduğu yerleşim birimini seviyorum." ş̧eklinde sunulan önermeye öğrencilerin sadece \%30,0'1 katılmaktadır.

Denekler Devletçe sağlanan yurt ve burs imkanlarını da yetersiz (sıras 1yla \%20,0 ve \%41,0) bulmaktadır. Sağlanan staj olanakları ise büyük ölçüde $(\% 70,0)$ yeterli görülmektedir. Stajlar orman işletme müdürlüklerinde yapilmaktadır.

MYO'ların ders programları genel itibariyle birbiriyle uyumlu olsa da bazı farklılıklar da söz konusu olabilmektedir. "Ders programı kapsaminda aldığımız/alacağımı dersler orman muhafaza memurluğu için yeterlidir. " önermesine deneklerin \%76,0'1 katıldığını ifade etmektedir. "Öğretim elemanlar eğitimine yeterli katkıyı yapmaktadır" önermesine katılım oranı ise $\% 85,0$ 'dır. Bununla birlikte özellikle orman fakültelerinin bulunmadığ 1 üniversitelerde açılan ormancıllkla ilgili programlarda ders vermek üzere görevlendirilen kişilerin ormanc1lk eğitimi verebilme konusundaki yeterlilikleri tartışılması gereken bir konudur (Alkan, 2013).

"Aldı̆̆ım ĕgitim orman muhafaza memurluğu yapabilmek için yeterlidir." Önermesine öğrencilerin \%81,0'1 katılım göstermektedir. Yani öğrencilerin önemli bir kısmı mesleği icra edebilmek için gerekli olacak eğitimi aldıklarını düşünmektedir. Daha önce ifade edildiği gibi farklı ilgi guruplarının konuya ilişkin görüşleri farklılıklar gösterebilmektedir. Her şeye rağmen, MYO'larda yetiştirilen öğrencilerin orman muhafaza memurluğu hakkında önemli bir alt yapı kazandı̆̆ını söylemek mümkündür. Zira, öğrencilere sunulan birçok önermeye de verilen cevaplardan bu sonuca ulaşılabilmektedir. 
Çizelge 20. Öğrencilerin çeşitli konularda yargılara ilişkin düşünceleri

\begin{tabular}{|c|c|c|c|c|c|c|}
\hline \multirow{2}{*}{ Önerme-yargilar } & \multicolumn{6}{|c|}{$\%$} \\
\hline & 5 & 4 & 3 & 2 & 1 & 6 \\
\hline Orman muhafaza memurluğu mesleği toplum nezdinde yeterince bilinmektedir & 21,1 & 37,3 & 22,3 & 13,5 & 5,3 & 0,5 \\
\hline Orman muhafaza memurluğu mesleği toplum nezdinde yeterince it ibar görmektedir & 24,1 & 37,2 & 2,4 & 12,1 & 2,7 & 0,5 \\
\hline $\begin{array}{l}\text { Muhafaza memuru yetiştirmeye yönelik açılan mevcut programlar yeterlidir. Yeni } \\
\text { programların açılmasıa karșıvm. }\end{array}$ & 35,9 & 22,1 & 21,2 & 11,9 & 7,3 & 0,6 \\
\hline $\begin{array}{l}\text { Orman muhafaza memurlarının dikey geçiş yoluyla orman fakült elerinde lisans eğitimi } \\
\text { alması meslek için yararlıdır. }\end{array}$ & 55,9 & 31,1 & 8,3 & 2,4 & 0,8 & 0,9 \\
\hline Mezun olur olmaz dikey geçişle orman mühendisliği bölümüne geçmeyi planlıyorum & 30 & 23,5 & 33,4 & 8,2 & 3,4 & 0,8 \\
\hline $\begin{array}{l}\text { Ormanlarımızın korunup gelişt irilebilmesi içinmuhafaza memurlarına mutlaka ihtiyaç } \\
\text { vardır. Bu ihtiyaç günden güne artmaktadır }\end{array}$ & 71,4 & 21,4 & 3,7 & 1 & 0,9 & 1,6 \\
\hline Orman Muhafaza memurlarının çalıșma koşulları hakkında yeterli bilgiye sahibim. & 26 & 46,9 & 18,3 & 5,7 & 1,6 & 1,4 \\
\hline Orma & 57,3 & 31,9 & 7 & 1,3 & 0,6 & 2 \\
\hline Orman muhafaza memur & 31,1 & 41,2 & 18,3 & 5,8 & 1,9 & 1,6 \\
\hline Muhafaza & 18,8 & 29,8 & 26,2 & 12,1 & 11,4 & 0,3 \\
\hline Orma & 19,1 & 31,5 & 27,8 & 12,1 & 7,5 & 2 \\
\hline Tekr & 34 & 24,1 & 19,3 & 7,8 & 13,0 & 1,6 \\
\hline Bize sağlanan staj olanaklarını yeterlidir & 30,3 & 38,7 & 17,4 & 6,8 & 5,1 & 1,6 \\
\hline $\begin{array}{l}\text { Okulumuzun fiziksel olanakları (Laboratuar, çalışma salonları, kantin, spor salonları, vb. } \\
\text { bakımdan) yeterlidir }\end{array}$ & 8,2 & 15,5 & 13,1 & 22,4 & 39,4 & 1,3 \\
\hline Okulumun bulunduğu yerleşim birimini (il, ilçe, vb.) seviyorum. & 11,9 & 17,2 & 16,1 & 16,1 & 36,8 & 0,3 \\
\hline $\begin{array}{l}\text { Ders programı kapsamında aldığımız/alacağımız dersler orman muhafaza memurluğu için } \\
\text { yeterlidir. }\end{array}$ & 36,9 & 38,9 & 13,7 & 4,9 & 4,2 & 1,1 \\
\hline Ögretim elemanları eğitimineyeterli katkıyıyapmaktadır & 46,1 & 36,9 & 8,3 & 3,2 & 3,4 & 2 \\
\hline Aldığım eğitim orman muhafaza memurluğ & 39,2 & 39,9 & 10,7 & 5,3 & 2,8 & 2 \\
\hline $\begin{array}{l}\text { Mezun olduktan sonra 1-2 yıl beklemeden at anarak orman muhafaza memurluğuna } \\
\text { başlayabileceğimi düșünüyorum. }\end{array}$ & 34,3 & 36,4 & 20,6 & 4,6 & 2,7 & 1,5 \\
\hline Mevcut muhafaza memuru alım şeklini uygun bulmuyorum. & 45,4 & 20,7 & 14,7 & 6,7 & 10,7 & 1,8 \\
\hline Devletçe sağlanan burs miktarını yeterlidir & 16,3 & 23,3 & 20,6 & 14,3 & 23 & 2,5 \\
\hline & 11,6 & 13,9 & 19,7 & 18,1 & 34,6 & \\
\hline Muhafaza memuru olarak atanamazsam tatmin edici başka bir iş bulma şansımyoktur. & 41,8 & 21,5 & 18,8 & 8,5 & 7,7 & 1,6 \\
\hline
\end{tabular}

* 5:Kesinlikle katılıy orum, 4:Katılıy orum, 3:Karazsızım, 2:Katılmıy orum, 1:Hiç katılmıy orum, 6:Cevapsız,

"Orman Muhafaza memurlarının çalıșma koșullan hakkında yeterli bilgiye sahibim" önermesine öğrencilerin katılım oran1 \%74,0'dır. "Orman muhafaza memurlarının çalışma koşullarına kolaylıkla uyum gösterebilirim." önermesine katılım ise oldukça yüksek $(\% 91,0)$ olup, sevindiricidir.

Öğrencilerin \%72,0’1 mezun olduktan sonra birkaç y1l içeris inde orman muhafaza memurluğuna atanabileceklerine inanmaktadır. Bununla birlikte sınav sistemi ve konuya ilişkin güncel gelişmeler konusunda ise endişeler bulunmaktadır. Orman muhafaza memurunun kimler arasından seçildiği kadar nasıl seçildiği de önemlidir. Mevcut haliyle KPSS ve mülakat sonucuna göre yerleştirmeler yapılmaktadır. Öğrencilerin muhafaza memuru seçim şekline ilişkin görüşlerinin belirlenebilmesi için "Mevcut orman muhafaza memuru alım şeklini (KPSS sınavl)nı uygun bulmuyorum. Sinav mesleki bilgi ölçmeye yönelik olmalıdır." önermesi kullanılmıştır. Alınan cevaplara göre öğrencilerin \%67,0'1 mesleki bilgi sorulmadan tamamen genel kültür ağırlıklı yapılan bir KPSS sınavına karș1 olduklarını ifade etmektedir. Bu konuda öğrencilerin \%15,0'1 kararsız iken \%18,0'l1k kesim ise bu sınav şeklinin uygun olduğunu ifade etmektedir. Bununla birlikte 20 Eylül 2014 tarihinde 29125 say1l Resmi Gazetede yayınlanan Orman Muahafaza Memurlarının Atama ve Yer Değiștirme Yönetmeliği ile beraber yapılan düzenlemelerle mülakat ve sözlü smav getirilmiștir. Sözlü sinavlara verilen tepkiler ve açılan davalar üzerine, 15.04.2014 tarihli Danıştay 12.Dairesinin kararı ile orman muhafaza memurlarının sözlü ve uygulamalı sınavla alınmasını öngören KPSS Yönetmeliği hükmü iptal edilmiștir. 20 Eylül 2014 tarihli resmi gazetede yayınlanan "Orman Muhafaza Memurlarının Atama ve Yer Değiştirme
Yönetmeliği ’ne göre ise KPSS sınavına ek olarak uygulama sınavı getirilmiştir.

\section{Sonuç ve öneriler}

Bir örgütün başarıya ulaşabilmesi personelin seçimi, eğitimi, etkin bir şekilde çalışmasına olanak sağlayacak görev tanımlarının yapılması, yetki-sorumluluklarının belirlenmesi, ast-üst ilişkilerinin ortaya konulması, atama ve yükselme ile ilgili hususların tanımlanmas1, motivasyonun sağlanmas1 ve hepsinden önemlisi aidiyet duygusunun kazandırılması ile yakından ilintilidir. $\mathrm{Bu}$ makalede ormanc1lı örgüt yapısı içinde önemli görevler üstlenmiş olan muhafaza memurlarına yönelik çözümlemeler yapılmıştır.

Orman muhafaza memurları ya da halk ağzında anıldı $\breve{g}_{1}$ şekilde ormancıların yakın zamana kadar toplum nezdinde kötü bir üne sahip oldukları söylenebilir. Bununla birlikte bu olumsuz algıların yasalardaki yumuşama ve eğitim düzeyinin artmas1 ile birlikte gün geçtikçe azaldığ 1 düşünülmektedir. Muhafaza memurluğunun toplum nezdindeki itibarı ve geleceğinin paydaşlarca tanımlanması istendiğinde öğrencilerin orman muhafaza memurlarına göre daha iyimser oldukları ortaya çıkmıştır. Muhafaza memurlarının yaklaşık yarısı firsat verilse başka bir iş yapmak istediğini üçte ikisinden fazlası da çocuklarının ya da akrabalarının orman muhafaza memuru olmasin 1 istemediklerini ifade etmektedir. Bunun en önemli nedenleri, çalışma koşullarının ağır ve iş yükünün ağır olmasına karşın sağlanan maddi ve manevi olanakların yetersizliğidir. Ayrıca, çalışma alanının büyüklüğü, teknik donanım yeters izliği, orman köylüsü ile sık sık karşı karşıya gelinmesi, kendilerine ormancılık örgütü içinde yeterince değer verilmemesi, vb. öne çikan diğer sorunlar olarak 
sıralanabilir. Söz konusu sonunlara bağlı olarak ortaya çıkan görevini tam olarak yerine getirememe, adli veya idari bir sıkıntı yaşanması durumunda kendini yalnız hissetme, yaptığ 1 işten memnun olmama gibi sorunlar ortaya çıkmaktadır. $\mathrm{Bu}$ sorunlar genel olarak incelendiğinde bir kısmının doğrudan orman teşkilatının girişimiyle çözüme kavuşturulabileceği görülmektedir. Bu bağlamda, orman muhafaza memurlarında kademe ilerlemesinin hayata geçirilmesi (Aksu, 2012), çalışma alanının sınırlandırılması, teknik donanımın iyileştirilmesi, performans-adaletli bir ödül-ücretlendirme sistemine geçilmesi, vb. motivas yon ve performans artımına yol açacaktır. Orman Bölge Müdürlüklerinde belirlenen norm kadro sayıs inda muhafaza memuru yoktur. Ayrıca dağılım bakımından da önemli sorunlar bulunmaktadır. Söz konusu olumsuzluklar da bir an önce giderilmelidir.

Orman muhafaza memurlarının en büyük sıkıntılarından biriside zorlu çalışma koşullarının sosyal hayatlarını olumsuz etkilemesidir. $\mathrm{Bu}$ ise memnuniyetsizlik oluşturmaktadır. Zira, 24 saat yangın nöbeti tutup ertesi gün tekrar işe gelen, haftasonu görev yerinden ayrilamayan memurlarının durumdan memnun olmasibeklenemez.

Daha önce ifade edildiği gibi orman muhafaza memurlarının kimler arasından seçileceği ve kimin tarafindan eğitileceği önemli bir konudur. Zaman zaman yapılan düzenlemelerle sadece MYO'lardan atama yapılırken, bazen liselere de firsat sunulabilmektedir. MYO'lar çeşitli işkollarına nitelikli teknik ara eleman yetiştiren yükseköğretim kurumlarıdır (YÖK, 2012; Alkan, 2013). Dolayısıyla 2012 yılındaki yasal düzenlemelerle birlikte yeniden gündeme gelen lise ve dengi okullardan orman muhafaza memuru istihdamı konusu Ülkemizin yükseköğretim politikalarına aykırı bir durumdur. MYO'lardan yapılan seçimlerde ise bazen birçok programdan seçim yapılırken bazen sadece ormancilı ve ilgili program-bölümlerden seçim yapılagelmiştir. Nitekim, 1993 y1lında yürürlüğe giren "Orman Muhafaza Memurlarının Atama ve Yer Değiștirmeleri Hakkındaki Yönetmeliğ $\imath$ "n 5.Maddesi'nde "Orman Muhafaza memurluğu için öğrenim durumu olarak; Yüksek Öğrenim Kurmlarnna bağli MYO'lardan mezun olanlardan öncelik strasina göre Orman Işletmeciliği, Av ve Yaban Hayatı, Fidan Yetisstirme, Harita ve Kadastro bölümlerinden veya lise ve dengi okullardan mezun olma şart aranır." denmektedir. 2009 yılında yürürlüğe giren yönetmelik ile "Orman muhafaza memurluğu için öğrenim durumu olarak; yükseköğrenim kurumlarına bağll ön lisans programlarından; Orman işletmeciliği, Ormancılık, Orman Ürünleri ve Odun Dışı Orman Ürünleri Bölümlerinden mezun olma şartı aranır." denmiştir. En son 2012 yılında yüürlüğe giren "Orman Muhafaza Memurları Atama ve Yer Değiştirme Yönetmeliği”nin 5.maddesinde 1993 yılındaki düzenlemelerle aynı ifadelere yer verilerek 2009 öncesi uygulamalara geri dönülmüştür (TOİ, 2012). Bununla birlikte, son alımlarda lise mezunlarınin ve ormancilıkla ilgili olmayan programlardan mezun olanların müracatlarının kabul edilmemesi olumlu bir gelişme olarak kabul edilebilir. Atanacak muhafaza memurlarının seçimi ise ormancılığa yönelik bir KPSS smavı ile olmalıdır. Sözlü sinavlar (her nekadar son düzenlemelerle adına uygulama sınav denilmişse de) meslek kamuoyunda tedirginlik yaratmaktadir.
MYO'larda verilen eğitim kadar öğrencilerin buna vermiş oldukları karşıllklar da önemlidir. MYO'lar öğrencilerinin büyük bir kısmını mesleki ve teknik liselerden sağlamaktadır. Bunun asıl nedeni 2002 yılından itibaren mes leki ve teknik orta-lise öğrencilerine MYO'lara sınavsız geçiş hakkı verilmesidir. Bu durumun öğrencilerin başarı durumuna olumsuz bir şekilde etki ettiğine yönelik bazı tespitler söz konusudur. Dolayıs ıyla bu geçiş sis teminin yeniden sorgulanması yararlı olacaktır (Alkan, 2013).

MYO'ların yeterlilikleri de sorgulanması gereken husulatrdan birisidir. Olumlu atanma koşulları nedeniyle ormanc1lkkla ilgili program ya da bölümlerin bir ve ikinci öğretim şeklinde sayıları hızla ve kontrolsüz bir şekilde artmıştır. Orman fakültesi bulunmayan üniversitelerde bile ormancılıkla ilgili iki yıllık programlar açılmıştır. Hatta Mersin Üniversitesi Mersin MYO'da açılan ormancıllk ve orman ürünleri programı örgün değil, uzaktan eğitim şeklinde eğitim vermeye başlamıştır (Alkan, 2013). Bu durum bir taraftan istihdam sorununu gündeme getirirken; diğer taraftan da verilen eğitimin kalitesini sorgulanır hale getirmiştir. Gelinen bu noktada MYO'larında verilen eğitimin kalitesinin çeşitli değişken ve ölçütler bakımından mutlaka sorgulanması gerekmektedir. Bulgular bölümünde ayrıntılı olarak belirtildiği gibi araştırmaya katılan öğrenciler mesleğe yönelik almış oldukları eğitimi yeterli görmektedir. Uygulamada çalışmakta olan orman muhafaza memurları eğitimin tam anlamıla yeterli görmezken, araştırmaya katılan orman mühendislerinin yarısından fazlası da MYO'larca verilen eğitimin orman muhafaza memurluğu için yeterli olmadığını ifade etmektedir. Anılan nedenlerle bu pogramların sayısinın artık arttırılmaması ve orman fakültesi olmayan yerlerde bu programların kesinlikle açılmaması gerekmektedir.

Üniversitelende eğitim, bilgi çağındaki gelişmeler 1şığında farklı süreçlerin bileşimi olarak ortaya çıkmakta ve mesleki eğitimin yanında sosyal, kültürel ve beşeri gelişimi de kapsamaktadır (Korkmaz vd. 2008). Bu bağlamda öğrencilere sağlanan fiziksel ve sosyal olanaklar önemli hale gelmektedir. MYO'ların önemli sorunlarından birisi de alt yapı eksikliği ve öğrenciler için yeterli fiziksel koşulların sağlanamamasıdır. Böyle durumlarda öğrenci tatmini azalmakta ve bu durum da eğitim kalitesine yansıyabilmektedir. Özellikle ormancılık ve orman ürünleri programlarını tercih eden öğrencilerin önemli bir bölümünün kırsal yerleşimlerden geldiği düşünüldüğünde üniversitelerin eğitim için gerekli fiziksel alt yapının yanında sosyal tesislere de önem vermesini zorunlu hale getirmektedir (Alkan, 2013).

Sonuç bölümünde ayrı bir başlık olarak incelenmesi gereken hususlardan birisi de dikey geçişle meselesidir. Orman muhafaza memurlarının bazıları bir taraftan memur olarak çalışırken, dikey geçişle orman fakültelerine geçmekte ve bir taraftan orman mühendisliğ eğitimi alırken, diğer taraftanda muhafaza memurluğu görevini yerine getirmeye çalışmaktadır. Dikey geçişle orman fakültelerinde mühendislik okumaya başlayan öğrenciler öğrenim hayatlarının devam etmeleri nedeniyle kurumlarına yeterli faydayı sağlayamadıkları gibi mezun olduklarında KPSS sınavına girmeden (kurum içi unvan değişikliği sinavlariyla) orman mühendis lerinin önüne geçebilmektedir. $\mathrm{Bu}$ durum özellikle araştırmaya katılan orman mühendislerinin büyük çoğunluğu tarafindan önemli bir sorun olarak kabul edilmektedir. Araştırmaya katılan orman 
mühendislerindin yarıdan fazlası orman muhafaza memurlarına böyle bir hakkın tanınmasinı uygun bulmamaktadır. Dikey geçişle orman fakültelerine geçen öğrenciler başta izin sorunu olmak üzere farklı sorunlarla da karşıllaşabilmektedir. İzin sonunu OGM'nin Bölge Müdürlüklerine yazmıs olduğu 10.12.2012 tarih ve 25699 sayılı emir yazısı ile daha önce eğitim gördükleri orman fakültelerinin bulunduğu illerdeki taşra birimlerine görevlendirilen orman muhafaza memurlarının geçici görevlerini iptal etmesiyle daha da önemli hale gelmiştir. Bu emirde 2013 yılından sonra bu tip görevlendirmelere kesinlikle izin verilmeyeceği de belirtilmektedir. Dolayısıyla yeni bir düzenleme yapılmadığ 1 taktirde dikey geçişle görev yapmakta olduğu il dişındaki bir orman fakültesine yerleşmiş olan orman muhafaza memurlarının lisans eğitimine devam etmeleri neredeyse imkansız hale gelmiştir. Söz konusu olumsuzluklar fakültelerde dikey geçiş ler için ayrılan kontenjanları sorgulanır hale getirmiştir. Örneğin, SDÜ Orman Fakültesi 2013-2014 Eğitim-Öğretim Y1lı için izin, devam, vb. benzeri sorunlar yaşanıyor gerekçesiyle dikey geçiş kontenjanı talebinde bulunmamıştır. Öte yandan, MYO'larda eğitim almakta olan öğrencilerin büyük çoğunluğu dikey geçişi kendileri ve meslek için gerekli-yararlı bulmaktadır. Eğitimin anayasal bir hak olduğu düşünüldüğünde dikey geçiş hakkının orman muhafaza memurları içinde bir hak olduğu söylenebilir. Ancak bir taraf yasal hakkını kullanırken, diğer tarafta orman mühendisleri mağdur birakılmaktadır. Zira unvan değişikliği koşulları açıktan atama şartlarına göre çok daha kolay gözükmektedir.

\section{Teșekkür}

$\mathrm{Bu}$ makalenin hazırlanmasinda "Ormancilıta Ara Teknik Eleman Sorununa Yönelik Çözümlemeler” isimli yüksek lisans tezinden yararlanılmıştır. Emeği geçen herkese teşekkür ederiz.

\section{Kaynaklar}

Aksu, F., 2012. Başlarken, Görev nöbeti tazelendi. Defne Dergisi, 372:1-2, Ankara.

Alkan, H., 2013. Ormancıllk ve orman ürünleri programı öğrencilerine yönelik bir araştırma. SDÜ Orman Fakültesi Dergisi, 14: 88-94.

Daşdemir, İ., 2003. Asli Orman Ürünlerinde Fiyat Analizi (Zonguldak OBM Örneği). ZKÜ Bartın Orman Fakültesi Yayınları, Bartın.
Daşdemir, İ., 2011. Dikili ağaç satı̧larının uygulaması üzerine değerlendirmeler. Bartın Orman Fakültesi Dergisi, 13: 71-79.

Demir, E., 2015. Dikili Satış Uygulamalarına Yönelik Sos yo-Ekonomik Çözümlemeler. Yüksek Lisans Tezi, SDÜ, Fen Bilimleri Enstitüsü, Isparta.

EA, 2015. Meslek liselilerine sınavsız geçiş avantajı sona eriyor. Eğitim ajans1, http://www.egitimajansi.com/haber/mes lek-lis elilerinesinavsiz-gecis-avantaji-s ona-eriyor-haberi-41292h.html, Erişim: 28.07.2015.

Eymen, U.E., 2007. SPSS 15.0 Veri Analiz Yöntemleri. İstatistik Merkezi Yayınları, Ankara.

Genç, M., Avcı, M., 2005. Ormancilikta teknik yardımcı eleman ihtiyacı ve eğitimi: SDÜ MYO Programları. Türk Ormancılığında Ulus lararası Süreçte Acil Eyleme Dönüştürülmesi Gereken Konular, Mevzuat ve Yapılanmaya Yansımaları, Orman Mühendisleri Odas1 Sempozyumu, 22-24 Aralık 2005, Antalya, 501-508 s.

Keskin, N., Koraltan, A., Öztürk, Ö., 2010. Pamukkale Üniversiteri Buldan MYO öğrenci profili. Ulusal MYO ÖğrenciSempozyumu, 21-22 Ekim 2010, Düzce, 1-10 s.

Koç, H., Kanat, M., Tolunay, A., 2007. Türkiye'de ön lis ans ormancılık eğitiminde mevcut durum, darboğazlar ve çözüm önerileri. Orman Kaynaklarının İşlevleri Darboğazlar, Çözüm Önerileri ve Öncelikler Sempozyumu, Bildiriler Kitab1, İstanbul, s.201-215.

Korkmaz, M., Alkan, H., Akyol, A., Tolunay, A., 2008. SDÜ Orman Fakültesi ögrrencilerinin fakülte kültürünü algılamaları. III. Ulusal Ormancılık Kongresi, Türkiye Ormancılar Derneği, 20-22 Mart 2008, Ankara, s.85-94.

Nartgün, Ş.S., Yüksel, E., 2009. Ahi Evran Üniversitesi Kaman MYO öğrencilerinin sosyo-ekonomik düzeylerinin belirlenmesi. Ahi Evran Üni. Eğitim Fak. Der., $10(2): 1-8$.

Özdamar, A., 2004. Paket programlar ile istatiksel veri analizi. Kaan Kitabevi, Es kiş ehir.

TOİ, 2012. Orman muhafaza memurluğu yönetmeliği hakkında duyuru. Tarım Orman İş Sendikası. Ankara.

Toksoy, D., Bayramoğlu, M., Ayaz, H. 2012. Ormancıllk örgütündeki orman mühendis lerinin yönets el ve örgüts el sorunları üzerine bir araştırma. KSÜ Doğa Bilimleri Dergisi, Özel Say1:180-184.

Tolunay, A., 2001. Ormanc1likta uygulayıcı teknik pers onel eğitimi. I. Ulusal Ormancilı Kongresi, Türkiye Ormancilar Derneği, 19-20 Mart 2001, Ankara, 252-266 s.

YÖK, 2012. Yüksek Öğretim Kanunu, http://www.yok.gov.tr/content/view/435/, Erişim:24.10.2015. 